\title{
PENGHIJAUAN SEBAGAI TERAPI PENYEMBUHAN UNTUK ORANG DENGAN GANGGUAN MENTAL
}

\author{
Welly ${ }^{1)}$, Suwandi Supatra ${ }^{21}$ \\ 1) Program Studi S1 Arsitektur, Fakultas Teknik, Universitas Tarumanagara, welly_thio@hotmail.com \\ 2) Program Studi S1 Arsitektur, Fakultas Teknik, Universitas Tarumanagara, ybhan50@gmail.com
}

\begin{abstract}
Abstrak
Kesehatan Mental yang baik merupakan idaman bagi setiap orang. Seseorang yang memiliki mental sehat dapat menikmati kehidupan sehari hari sehingga dapat mempunyai hubungan sehat dengan orang lain. Sebaliknya orang dengan gangguan mental akan memiliki gangguan kendali emosi yang pada akhirnya bisa mengarah pada perilaku buruk. Hingga saat ini masyarakat pada umumnya masih memiliki stigma negatif pada pengidap penyakit mental hingga menyebabkan banyak diantara mereka yang diperlakukan secara buruk. Oleh karena itu, dalam membantu mengurangi dan mengatasi tingginya angka pengidap gangguan mental, Diperlukan sebuah wadah rehabilitasi yang dapat secara efektif merestorasi keadaan mental salah satunya dengan metode ecopsychology taman terapi yang membawa gagasan koneksi dengan alam sebagai fokus utama dalam penyembuhan.Penggunaan tanaman dan kegiatan terkait kebun dapat digunakan untuk meningkatkan kesejahteraan. Kegiatan mungkin termasuk menggali tanah, menanam bibit, menyiangi taman, dan memotong daun. Kegiatan ini dapat direkomendasikan dalam kasus stres, kelelahan, penyalahgunaan zat, serta dalam kasus isolasi sosial. Diharapkan proyek Penghijauan Sebagai Terapi Penyembuhan Untuk Orang Dengan Gangguan Mental dapat menyembuhkan para pengidap gangguan mental secara keseluruhan sehingga mereka dapat menjalani kehidupan seperti orang biasa.
\end{abstract}

Kata kunci: Gangguan Mental; Kesehatan; Taman Terapi

\begin{abstract}
Good mental health is a dream for everyone. Someone who has a mental health can enjoy daily life so that he can have healthy relationships with others. Conversely, people with mental disorders will have emotional control disorders that can ultimately lead to bad behavior. Until now, the community in general still has a negative stigma towards people with mental illness, causing many of them to be treated badly. Therefore, in helping reduce and overcome the high number of people with mental disorders, A rehabilitation center is needed that can effectively restore mental states, one of which is the ecopsychology method of therapeutic gardens that brings the idea of connection with nature as the main focus in healing. The use of plants and garden-related activities can be used to improve welfare. Activities may include digging soil, planting seeds, weeding the garden, and cutting leaves. This activity can be recommended in cases of stress, fatigue, substance abuse, as well as in cases of social isolation. It is hoped that the Project of Greeneny as a Healing Therapy for People with Mental Disorders can cure people with mental disorders as a whole so that they can live their lives like ordinary people.
\end{abstract}

Keywords: Health; Mental Disorders; Therapeutic Garden 
Millennial generation atau generasi $Y$ juga akrab disebut generation me atau echo boomers. Pada 2018, BPS memproyeksi jumlah penduduk Indonesia mencapai 265 juta jiwa. Pada 2019, jumlah millenial diproyeksi sebanyak $23,77 \%$ dari total populasi Indonesia yang mencapai 268 juta jiwa. Artinya, hampir seperlima penduduk di Indonesia adalah kelompok milenial. Generasi ini merupakan orang-orang dengan usia produktif yang hidup bersamaan dengan pesatnya perkembangan era digital dan internet. Secara bersamaan memiliki banyak permasalahan seperti sulitnya keadaan ekonomi, sulit dapat pekerjaan dan tren pekerjaan kontrak. Akibatnya, generasi muda ini merasa tak aman secara finansial. Banyak dari mereka kesulitan menemukan pekerjaan yang dibayar cukup. Apalagi mendapat tawaran jenjang karir yang baik. Kesulitan ini dapat memicu kecemasan, stres, dan depresi.

Studi The Health Foundation melansir milenial sebagai generasi yang tidak bahagia dan kurang sehat dibandingkan generasi terdahulu. Laporan ini menyebut ketiadaan pekerjaan yang berkualitas membuat generasi milenial rawan perilaku hidup tidak sehat, seperti merokok dan konsumsi alkohol yang berpengaruh buruk pada kesehatan. Data ini sejalan dengan data Hasil Riset Kesehatan Dasar 2018 dengan jakarta memiliki prevalensi gangguan kesehatan jiwa berat di angka 7 permil. Artinya dapat diperkirakan bahwa penderita gangguan jiwa berat di Jakarta mencapai 73.273 jiwa dari jumlah penduduk Jakarta saat kini yaitu 10.467.600 jiwa. Angka prevelensi ini naik signifikan 4 kali dari data Hasil Riset Kesehatan Dasar 2013 yang menunjukkan prevelensi 1.1 di angka 11.110 jiwa.sedangkan keadaan rumah sakit jiwa di Jakarta dinilai masih kurang dan belum memenuhi standar kebutuhan penduduk Jakarta.

Itulah sebabnya proyek Penghijauan Sebagai Terapi Penyembuhan Untuk Orang Dengan Gangguan Mental ini diajukan sebagai usulan proyek pada program Studio Perancangan Aritektur 8.2.7.Proyek ini merupakan bangunan kesehatan yang Berhubungan langsung dengan ruang hijau Therapeutic yang berperan membantu dalam mengurangi dan mengatasi tingginya angka pengidap gangguan mental di Jakarta khususnya dari masalah tingginya tingkat stress kaum Millenial Muda yang sayangnya seringkali dianggap remeh oleh masyarakat.

\section{KAJIAN LITERATUR}

\section{Arsitektur Perilaku dan Kesejaman}

Arsitektur perilaku adalah arsitektur yang manusiawi, yang mampu memahami dan mewadahi perilaku-perilaku manusia yang ditangkap dari berbagai macam perilaku, baik itu perilaku pencipta, pengamat, dan juga perilaku alam sekitarnya (Mangunwijaya, Y. B., 1988). Berarsitektur perilaku merupakan pendekatan yang menyelidiki hubungan perilaku manusia dengan lingkungan arsitektur sebagai pertimbangan penerapan desain. Pertimbanganpertimbangan ini pada awalnya dibutuhkan untuk perancangan obyek-obyek arsitektur tertentu, misalnya rumah sakit jiwa rehabilitasi narkoba, penjara, dan rumah sakit anak atau pusat autisme. Disebutkan bahwa arsitektur adalah sebuah penciptaan suasana, yang artinya adalah perkawinan antara guna dan citra. Guna merujuk pada manfaat yang ditimbulkan dari hasil rancangan.

\section{Psikosis Atau Gangguan Mental}

Gangguan mental sering disebut psikosis dalam Bahasa kedokteran, Pemulihan pasien yang mengalami psikosis inilah yang merupakan fungsi utama dari Rumah Sakit Jiwa. Keadaan ini bermula dari Stress dan berkembang menjadi Depression kemudian menjadi Schizopphernia. W.F. Maramis (2005 : 180), menyatakan bahwa psikosis adalah suatu gangguan jiwa dengan kehilangan rasa kenyataan (sense of reality). Kelainan seperti ini dapat diketahui berdasarkan gangguan-gangguan pada perasaan, pikiran, kemauan, motorik, dst. Prilakau penderita psikosis tidak dapat dimengerti oleh normal, sehingga orang awam menyebut penderita sebagai orang gila.Dengan bermacamnya karakteristik dari psikosis tentunya dapat diterapkan strategi penyembuhan yang tepat dengan perwujudan desain yang sesuai.

Pengobatan gangguan jiwa 


\section{a. Terapi Modalitas}

Terapi modalitas bertujuan agar pola perilaku atau kepribadian seperti keterampilan koping, gaya komunikasi dan tingkat hargadiri bertahap dapat berkembang, mengingat bahwa klien/pasien dengan gangguan jiwa membutuhkan pengawasan yang ketat dan lingkungan suffortif yang aman. Contohnya: Psikoterapi, Psikoanalisis , Psikoterapi individu, Terapi modifikasi lingkungan, Psikoterapi individu, Terapi okupasi.

\section{b. Terapi Lingkungan}

Perawatan klien pada rumah sakit jiwa dalam jangka waktu yang lama mengkibatkan klien mengalami penurunan kemampuan berfikir dan bertindak secara mandiri dan kehilangan hubungan dengan dunia luar, oleh karena itu diperlukan pengembangan layanan keperawatan psikiatrik salah satunya dengan penerapan terapi lingkungan di rumah sakit.

\section{c. Terapi Somatik}

Terapi somatik adalah terapi yang diberikan pada pasien dengan tujuan merubah perilaku yang maladaptif menjadi perilaku yang adaptif dengan melakukan tindakan dalam bentuk perlakuan fisik.

\section{Therapeutic Healing Garden}

Therapeutic Healing Garden adalah Taman terapi yang menerapkan metode penyembuhan penyakit jiwa dengan membawa gagasan koneksi dengan alam sebagai fokus utama dalam penyembuhan. Penggunaan tanaman dan kegiatan terkait kebun dapat digunakan untuk meningkatkan kesejahteraan pendekatan restoratif melalui ruang lanskap outdoor, didalamnya terdapat perpaduan Antara soft landscape dan hard landscape yang ditujukan untuk mencapai bentukan desain yang interaktif dan terintergrasi antara ruang indoor bangunan dan area terapi outdoor, untuk menciptakan koneksi pada layaknya pada alam seperti kegiatan jalan ,duduk, berkebun, observasi di taman. Garden Taman merepresentatifkan alam yang dianggap inheren dalam proses penyembuhan pasien.

\section{Healthcare Design}

Desain sebuah pusat kesehatan yang baik bertujuan untuk memfasilitasi efektifitas penyembuhan. Rumah sakit umumnya menjadi panduan dalam mendasain suatu pusat kesehatan. Rumah Sakit perkotaan umumnya menggambarkan perpaduan antara dua tipologi dasar, distribusi gabungan, dengan beberapa komposisi bangunan dengan ketinggian sedang. Dasar untuk tipologi bangunan berasal dari konteks fisik proyek struktur kota atau lapangan hijau. Berdasarkan dari klasifikasi yang dilakukan dalam research pada jurnal size and complexity of hospitalsmatter for quality of care dapat dihipotesakan sebagai berikut:

a. Rumah sakit baru berkinerja lebih baik dari pada rumah sakit lama

b. Rumah sakit kecil berkinerja lebih baik dari Rumah sakit besar

c. Rumah Sakit Kompak mempunyai pelayanan yang lebih baik

d. Rumah Sakit yang berintergrasi mempunyai performa lebih baik

Suatu perwujudan desain yang baik menjadi sebuah hal yang penting dalam menentukan baik atau buruknya pusat kesehatan. Dengan landasan teori yang matang memungkinkan lahirnya desain yang mendukung performa penyembuhan pengguna didalamnya.

\section{METODE}

Dalam penyusunan laporan perancangan ini, Studi telah dilakukan dalam beberapa tahapan dasar yang di lalui dalam suatu evaluasi pada perancangan proyek, kemudian dirangkum secara sistematis sehingga dapat menambah bahan pengetahuan megenai proyek ini. Tahapan 
- tahapan inilah yang menjadi data untuk disusun menjadi satu kesatuan. Rangkaian penulisan dengan penarikan kesimpulan dari keadaan yang umum atau penemuan yang khusus dari yang umum yang disebut sebagai metode deduksi. Berikut merupakan tahapan yang dilalui dalam bahasan laporan antara lain:

a. Studi terhadap hubungan arsitektur, tipe dan perilaku serta nilai kesejamanan dalam hal ini keterkaitan dengan generasi millenial.

b. Studi terhadap karakteristik perilaku generasi millenial dalam permasalahan yang dihadapi.

c. Studi terhadap permasalahan kesehatan jiwa di Indonesia khususnya Jakarta.

d. Studi tipologi healthcare dari proyek-proyek serupa.

e. Observasi Lapangan melalui Survei dan pendataan awal keadaan lingkungan sekitar tapak.

f. Analisis tapak dan lingkungan.

g. Pengolahan data dan studi pustaka sehingga didapatkan karakteristik proyek yang berguna untuk perancangan awal.

h. Penerapan desain arsitektur sesuai kebutuhan yaitu dengan menghasilkan fasilitas yang memiliki terapan medikasi berkonsepkan alam sehingga menyembuhkan para pengidap gangguan mental secara keseluruhan

\section{DISKUSI DAN HASIL}

\section{Analisa Kawasan}

Analisa kawasan dimulai mengobservasi keadaan healthcare dari Jakarta keseluruhan. Dengan dipilihnya Jakarta Barat yang memiliki tingkat kepadatan penduduk yang tinggi dan memiliki pusat kesehatan mental utama yaitu Rumah Sakit Jiwa Dr. Soeharto Heerdjan. Dengan menganalisa keadaan kesehatan mental yang ada untuk mendapatkan gambaran tentang lokasi dari kawasan yang sesuai dalam menerapkan program rehabilitasi alam. Maka Kawasan yang dipilih dari satu Jakarta barat adalah Lokasi JI. Duri Ps., Duri Sel., Tambora, Kota Jakarta Barat, Daerah Khusus Ibukota Jakarta yang terletak di depan kawasan ITC Roxy Mas \& Juga dekat dengan Stasiun duri atau yang dikenal sebagai kawasan duri pulo.

Kawasan ini merupakan lahan strategis terletak dipusat kota yang besar memiliki total luas lahan 16 hektar namun masih 98 persen pembebasanya oleh pihak Pt. Sinarmas, kawasan ini merupakan kawasan yang telah terdampak pembebasan lahan karena dinilai banyak masalah seperti pemukiman padat dibantaran kali ciliwung yang tidak higienis, rawan kejahatan juga banyak permasalahan sosial, namun Kedepannya bila lahan sudah terbebas total, kawasan ini kedepanya akan segera menjadi kawasan masterplan multiguna dan komersil yang mendukung perekonomian kota Jakarta. 

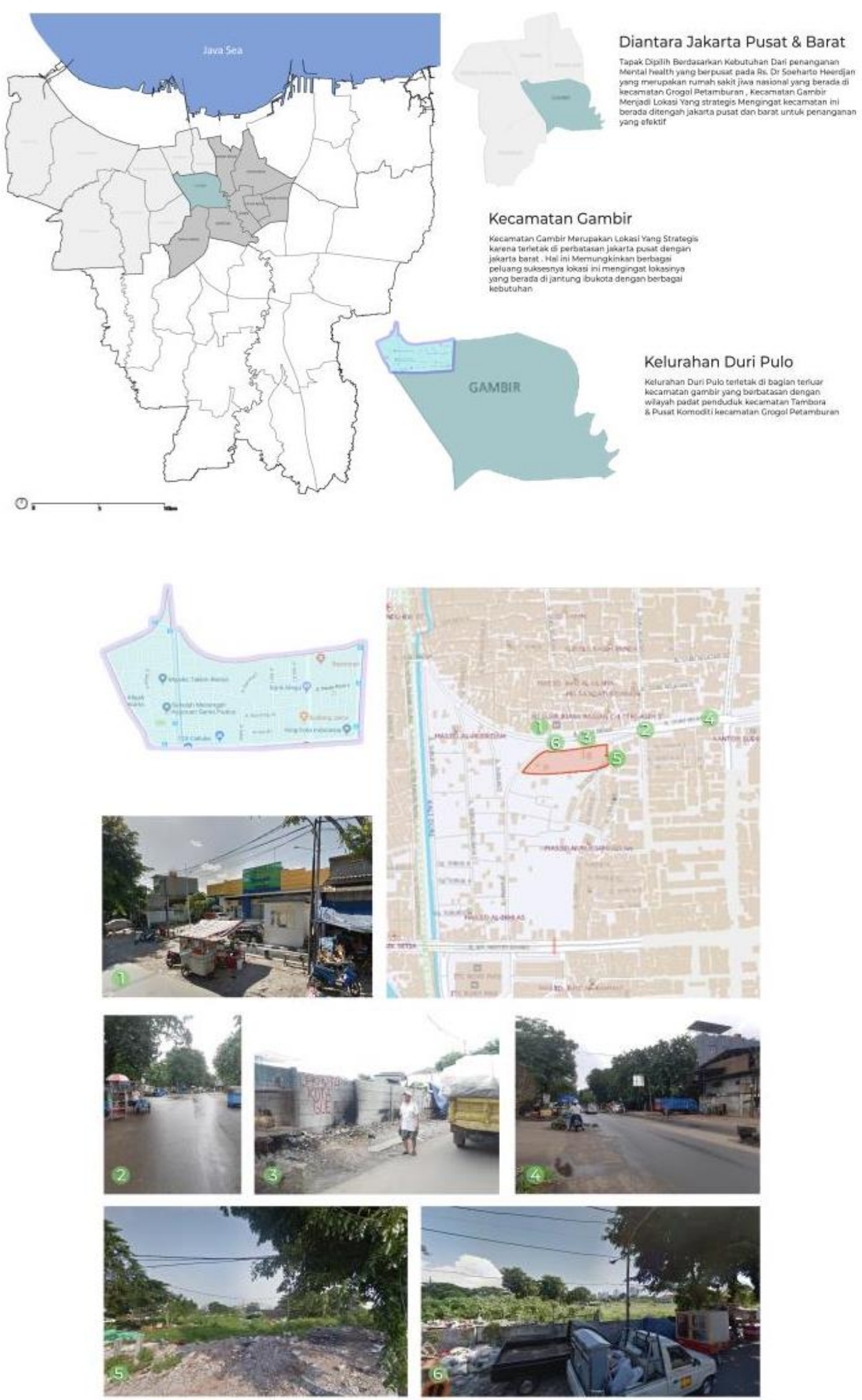

Gambar 1. Analisa Kawasan

Sumber: Penulis, 2019 


\section{Analisa Tapak}

Analisa Tapak dimulai dari menentukan pada kawasan Duri pulo dengan besaran 9,466 m yang pembebasan lahannya telah hampir selesai sebagaimana yang bisa dilihat pada dokumentasi pribadi saya terdapat pagar beton setinggi 2.5 meter mengelilingi kawasan ini bertujuan untuk mencegah pembangunan liar kembali juga telah banyak yang terelokasi, Kawasan ini berada di pusat kota sekaligus juga menjembatani antar pemukiman padat penduduk Duri pulo \& sekitar dengan kawasan layer utama di Jakarta. kedepannya akan ada pelebaran jalan, penambahan fasilitas juga perbaikan fungsi infrastruktur keseluruhan seperti pengadaan jalan ke stasiun duri, normalisasi kali ciliwung, ruang terbuka hijau, menjadikannya sebagai lahan multiguna komersil yang sangat strategis.

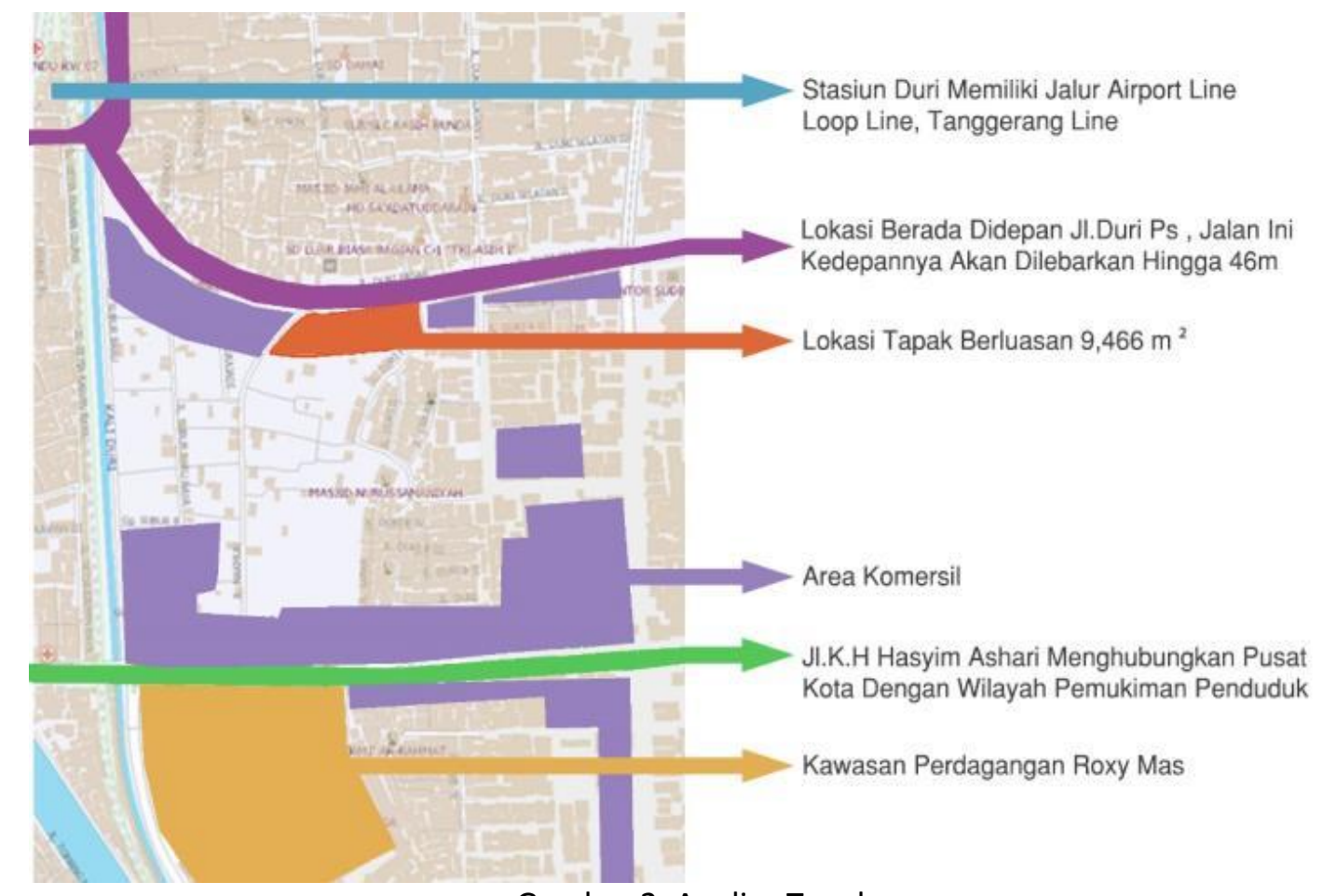

Gambar 2. Analisa Tapak

Sumber: Penulis, 2019

\section{Konsep}

Konsep perancangan pada proyek ini berfokus pada tema utama yaitu wadah pengembangan dengan mengambil konsep wadah rehabilitasi yang dapat secara efektif merestorasi keadaan mental. pada tema Nature assisted Healing yang diterjemahkan \& dipraktekkan dalam desain berupa therapeutic healing garden, Dimana pengguna dapat merasakan kontribusi alam bagi kehidupan dalam prosesnya merestorasi keadaan kesehatan. Desain bangunan ini diambil dari perpaduan Antara alam dan massa bangunan yang diambil dari teknik terasering dan juga prinsip golden ratio da vinci yang perpaduannya keduanya melahirkan design scheme pada bangunan. Diharapkan desain dengan bentukan organis dan terasering ini dapat membuat pengguna merasa benar benar ada di hutan \& pegunungan. Konsep ini akan membuat seseorang tidak merasa terbebani menjalani proses terapi sehingga proses medikasi bisa berjalan dengan sempurna. 


\section{Strategi Perancangan}

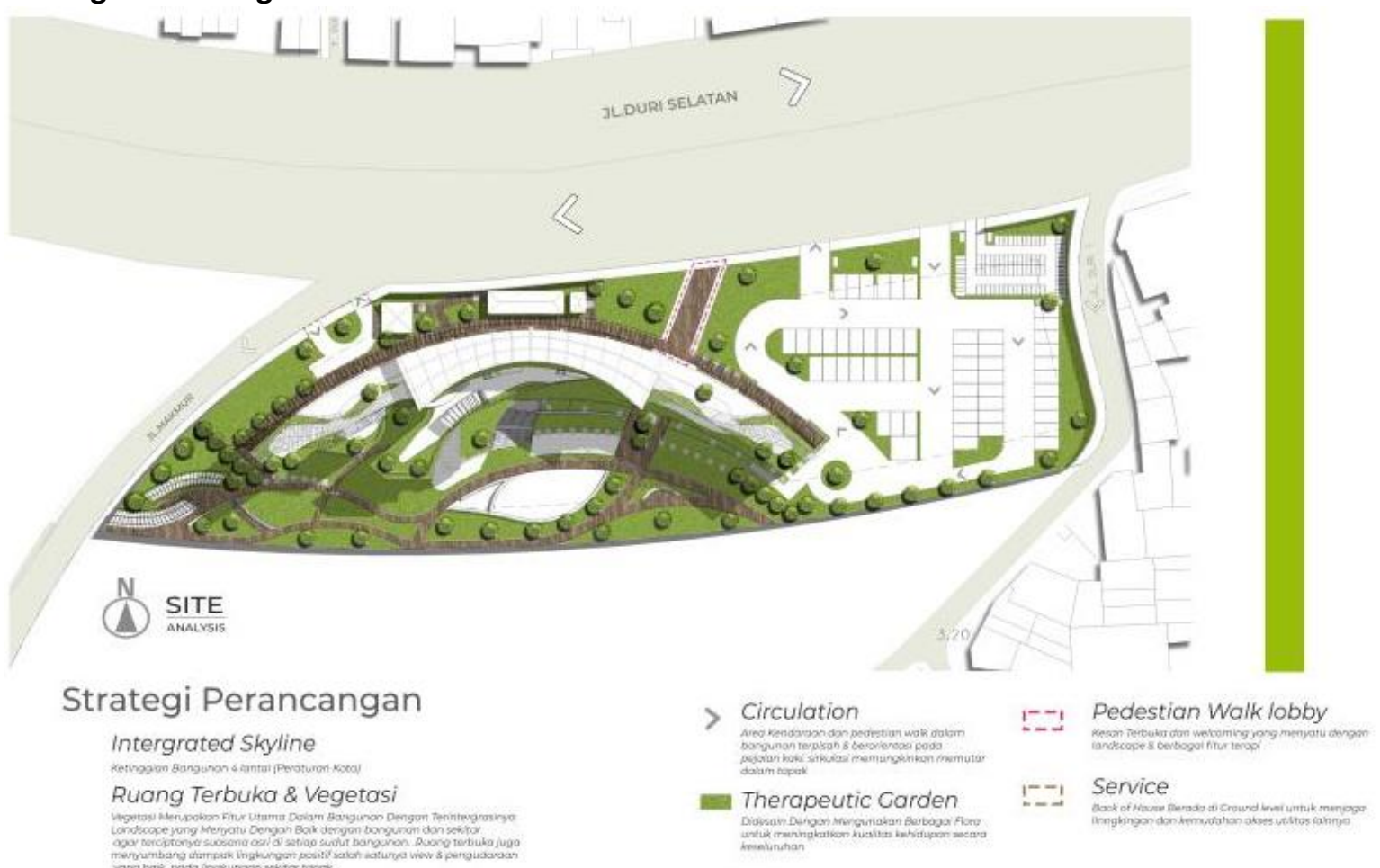

Gambar 3. Strategi Perancangan

Sumber: Penulis, 2019

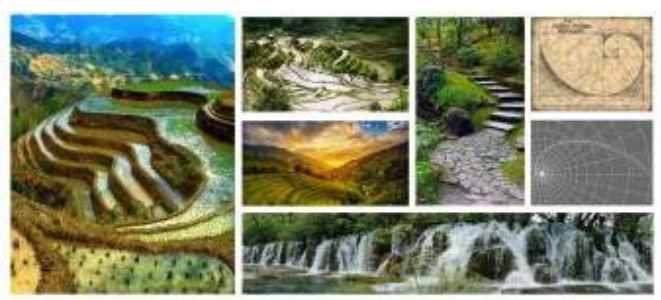

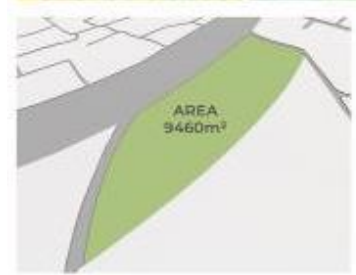

1 SITE $\begin{array}{lll}\text { KDB: } 60 & \text { KDH: } 30 \quad \text { KLA: } 2.4 \\ \text { CSE } 10 M & \text { CSS } 8 M & \end{array}$

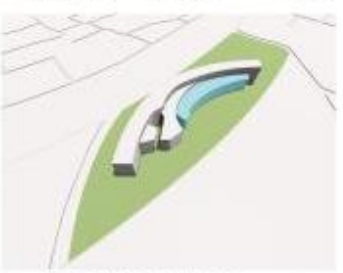

5 OPENING ATRIUM

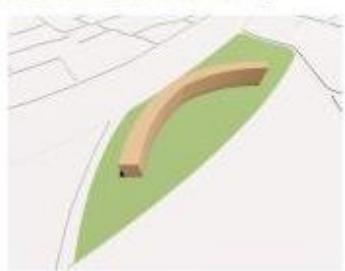

2 BASIC MASS

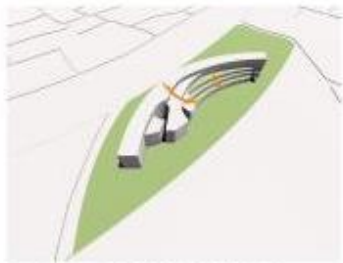

6 TERRACING \& PLAZA
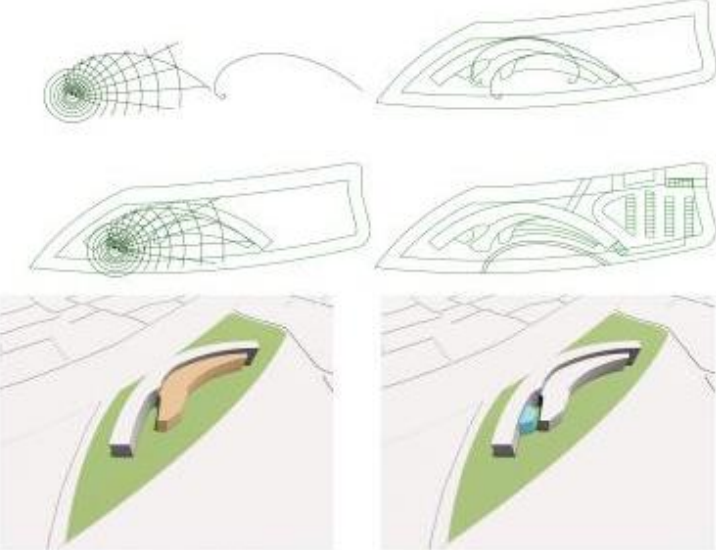

3 SECONDARY MASS

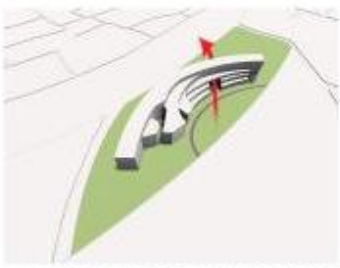

7 PUNCTURING ENTERANCE
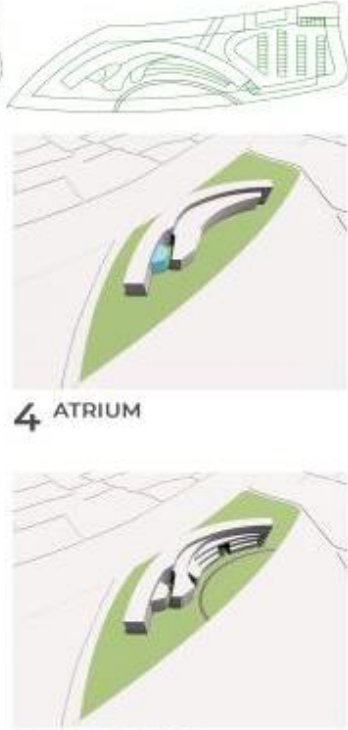

8 FINAL MASS

Gambar 4. Proses Gubahan Massa

Sumber: Penulis, 2019 


\section{Program}

Program utama dari bangunan adalah Theupupetic Healing Garden, merupakan taman yang bertujuan untuk membawa efek restoratif terhadap kesejahteraan mental pengguna. dengan menggabungkan fitur yang memfasilitasi terapi hortikultura, didalamnya terdapat berbagai penerapan program berupa zona-zona seperti Biodiversity zone, Fragrance zone, Colours \& Textures zone, dan Edible \& Medicinal zone dari penggunaan keseluruhan kegiatan yang berkaitan dengan tanaman, seperti berkebun untuk kesehatan. Program kedua adalah Collaboration. Program yang termasuk ke dalam Collaboration adalah Learrning \& Gardening Together. Program ketiga adalah Hospitality yang memfasilitasi kegiatan perawatan pasien.

\section{Programmatik Greenery As Healing For People With Mental Disorder 무밈}
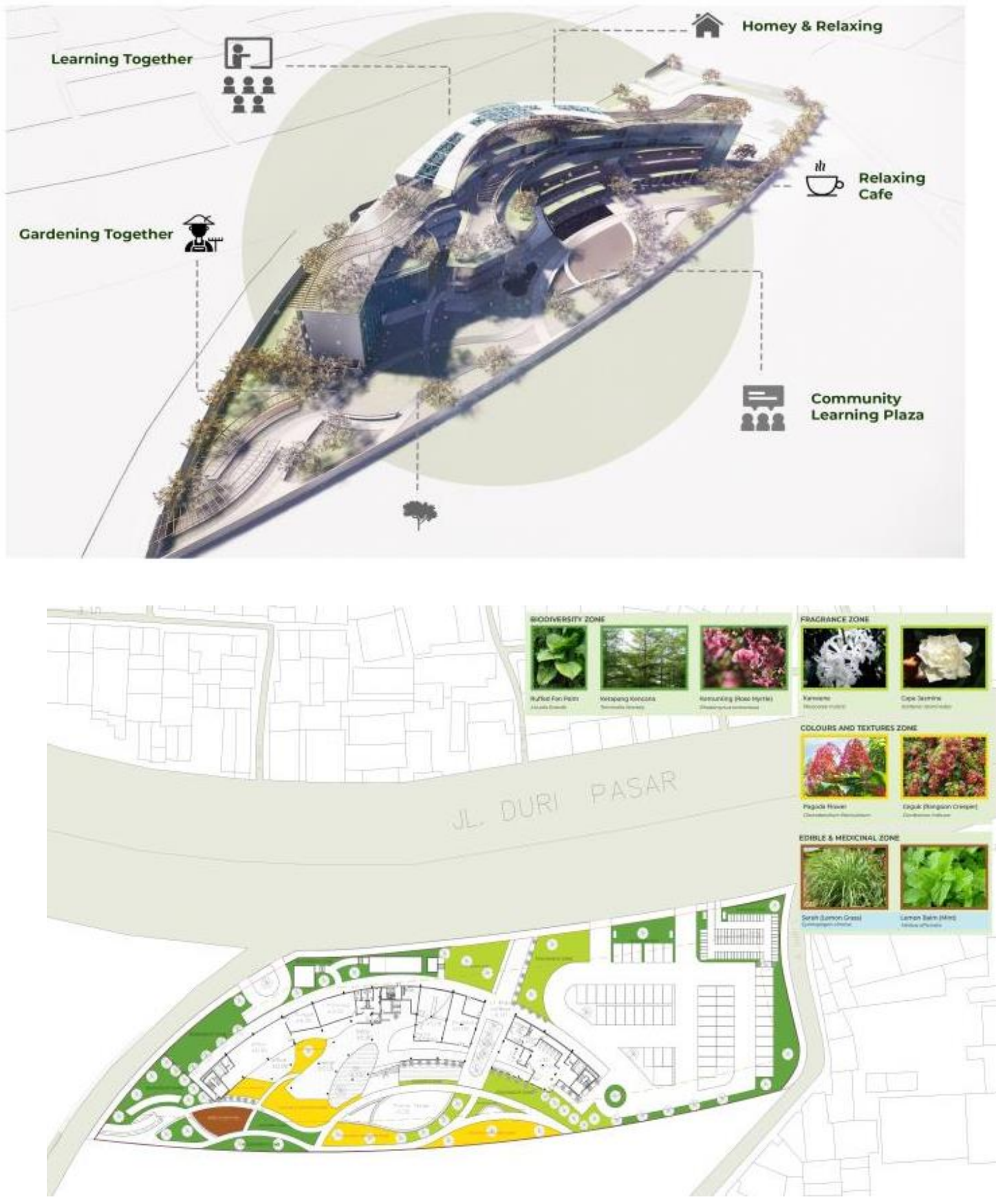

Gambar 5. Progammatik Greenery

Sumber: Penulis, 2019 
Struktur bangunan disesuaikan mengkuti massa dengan hasil desain terdapatnya ruang ruang split level. Kolom dibagi menjadi kolom induk dan kolom anak untuk menopang bangunan.Bagian kolom menggunaan kolom beton dengan dimensi $30 \times 60$ \& kolom diameter 40. Besar kolom beton dihitung dengan menggunakan hitungan $1 / 12$ bentang. Untuk bahan balok menggunakan bahan beton dengan ukuran 30/60 untuk ukuran balok induk dan ukuran 20/40 untuk ukuran balok anak. Plat lantai yang digunakan menggunakan bahan beton bertulang dengan ketebalan $15 \mathrm{~cm}$. Sedangkan pada bagian atap menggunakan rangka spaceframe serta penutup atap menggunakan glass panel \& Solid panel.

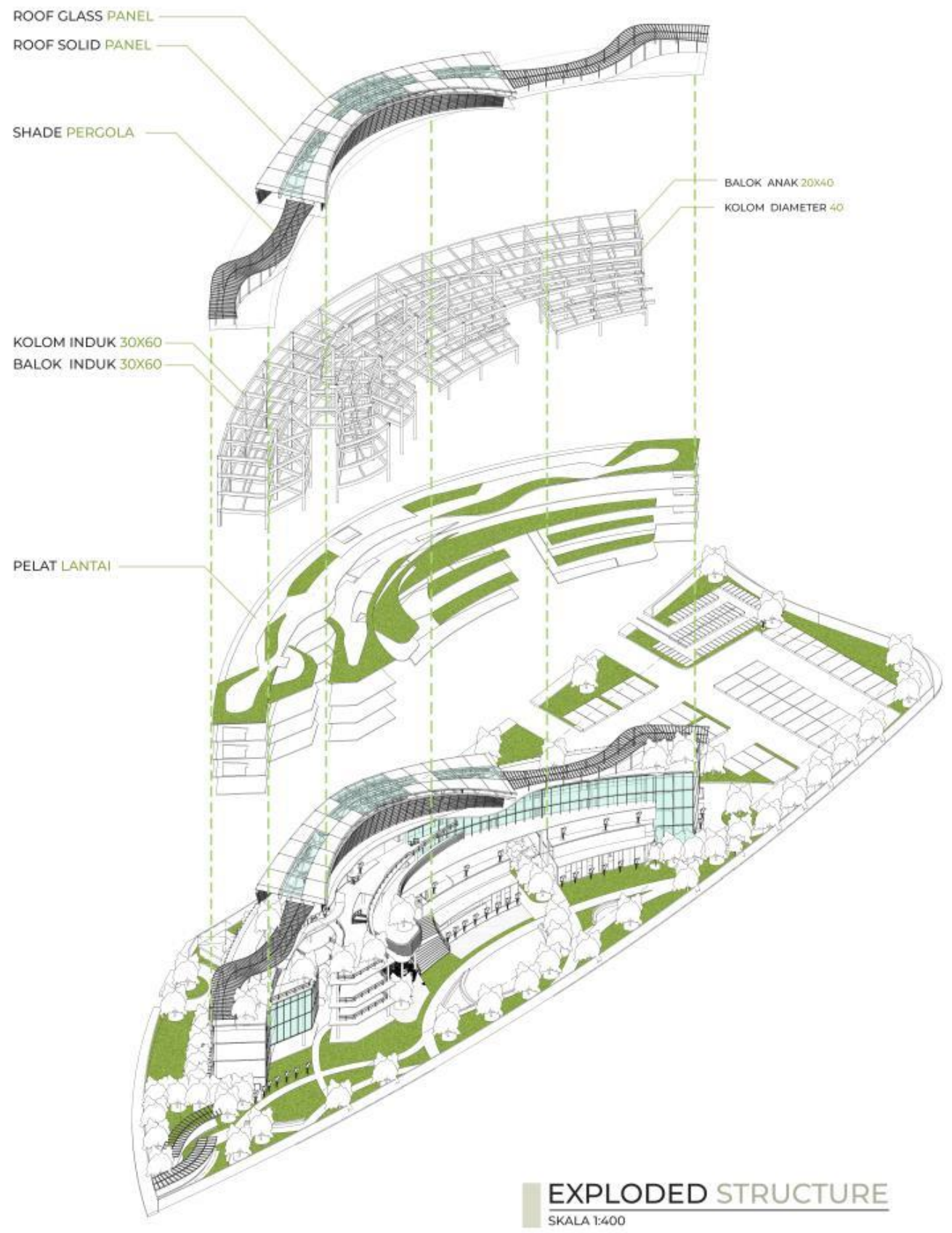

Gambar 6. Sistem Struktur Bangunan

Sumber: Penulis, 2019 


\section{KESIMPULAN DAN SARAN}

Kesejamanan Merupakan topik yang menarik bagi arsitektur karena didalamnya menceritakan bagaimana User memiliki kekuatan pada zamanya menentukan hasil dari Tipologi yang dihasilkan, Millenial sebagai generasi yang mendominasi jumlahnya tentunya tidak lepas dari intrik dan masalah masalah kehidupan, Millenial sebagai generasi muda sering dikatakan kurang bahagia, karena itu generasi ini mengidap jumlah stress \& depresi yang tinggi, angka ini terus naik dibuktikan dengan hasil Riset Kesehatan Dasar yang berlipat 4 kali dari tahun 2013 ,Proyek Penghijauan Sebagai Terapi Penyembuhan untuk orang dengan gangguan mental hadir bagi para millennial dalam menghadapi masalah kejiwaan yang mungkin selama ini dianggap tabu, Suasana Rehab Center yang baik akan memperbaiki stigma masyarakat dengan melakukan penyuluhan \& penelitian sebagaimana diketahui gangguan jiwa banyak variasinya dari yang ringan sampai berat, seringkali penyakit ini dianggap tabu dan ditutupi sehingga banyak pasien yang mendapatkan perlakuan tidak baik seperti dipasung .Dengan adanya fasilitas ini diharapkan penderita ganguan jiwa dapat perlakuan yang baik juga mengganti stigma tersebut dan pasien yang keluar siap menjalani kehidupan dengan norma-norma di masyarakat.

Healthcare Psychiatric berperan dalam mencari solusi yang merevolusi dengan menyesuaikan kebutuhan millennial pada pelayanan psikiatrik untuk lepas dari tekanan kehidupan, Proyek ini menjadi penting dikarenakan persepsi negative dari masyarakat hendaknya dapat dihindarkan dengan perwujudan desain yang humanis karena disini pasien tidak diperlakukan buruk melaikan diperlakukan sebagai seorang yang sangat butuh kasih sayang dalam proses penyembuhannya.

\section{REFERENSI}

Badan Penelitian dan Pengembangan Kesehatan Kementrian Kesehatan RI. (2018). Riset Kesehatan Dasar.

Ester. (2016). Mengenai Generasi Millenial. https://www.kominfo.go.id. 13 Februari 2019.

Gunarsa, S.(1998). Psikologi Perawatan. Jakarta: Pt. Bpk Gunung Mulia

Holst, M. K. (2015). Optimal Hospital Layout Design. Disertation.AALBORG UniversityDenmark. https://.vbn.aau.dk. 8 Februari 2019.

Liliek, S. (2016). Sejarah Psikiatri. https://dokumen.tips/documents/sejarah-psikiatri56b867c6a0624.html. 13 Februari 2019.

Mangunwijaya, Y.B. (2013). Wastu Citra. Jakarta : PT Gramedia Pustaka Utama

Neufert, E. (2002). Data Arsitek jilid II edisi 33. Terjemahan Sunarto. Jakarta: Erlangga

Novaya, S. (2016). Terpasung: Foto-foto Rumah Sakit Jiwa di Indonesia Ini Pasti Bikin Hatimu Teriris.https://www.idntimes.com. 13 Februari 2019.

Sailer, K. (2015). Size and Complexcity of hospital matter for quality of care. https://www.researchgate.net/publication/280533468 size and complexity of hospital s matter for quality of care A spatial classification of NHS buildings. 9 Februari $\underline{2019}$

Wiramihardja, S. A. (2005) .Pengantar Psikologi Abnormal. Bandung: Refika Aditam.

Zahra P., Poyan R. M. (2017). Therapeutic Gardens Evidence-Based Design Approach*. https://www.academia.edu/36696742/Therapeutic_Gardens_Evidence-

Based_Design_Approach. 9 Februari 2019. 